\title{
A CONCEPTUAL FRAMEWORK FOR HIGHER EDUCATION FACULTY MENTORING
}

\author{
Pamela S. Lottero-Perdue, Towson University \\ Steve Fifield, University of Delaware
}

There is considerable variability in conceptions of faculty mentoring in higher education. Rather than view this diversity as a problem, we see it as a potential resource that can inform design, implementation, and evaluation of faculty mentoring. To learn from this diversity, we review the literature on faculty mentoring in higher education to create a conceptual framework of mentoring. The conceptual framework is a tool that program administrators, participants, and evaluators can use to adapt mentoring to the unique needs of particular faculty and institutions.

Claims about the benefits of mentoring are widespread in professional and career development literature (Allen, Eby, Poteet, Lentz, \& Lima, 2004; Luna \& Cullen, 1995; Morrison-Beedy, Aronowitz, Dyne, \& Mkandawire, 2001; Spencer, Tribe, \& Sokolovskaja, 2004). But a close reading of conceptual, programmatic, and empirical studies reveals considerable variability in how mentoring is understood and put into practice

\footnotetext{
This publication was made possible by Grant Number 2 P20 RR016472-06, under the INBRE program of the National Center for Research Resources, a component of the National Institutes of Health (NIH). Its contents are solely the responsibility of the authors and do not necessarily represent the official views of NIH. This publication was also based upon work supported by the National Science Foundation (NSF) under Grant Nos. EPS-0408729 and EPS-0814251. Any opinions, findings, and conclusions or recommendations expressed in this material are those of the authors and do not necessarily reflect the views of the NSF. Thanks to Gabriele Bauer and three anonymous reviewers.
} 
(Borisoff, 1998; Davidson \& Foster-Johnson, 2001; Goodwin, Stevens, Goodwin, \& Hagood, 2000; Healy \& Welchert, 1990; Mertz, 2004; Sands, Parson, \& Duane, 1991; Wunsch, 1994a). The many meanings and practices collected under the term mentoring suggest that we take care when looking to the literature for help in designing, implementing, and evaluating mentoring.

One response to variable conceptions of mentoring is to develop a single definition broad enough to cover all circumstances. A few mentoring researchers have proposed consensus definitions or unifying models of mentoring (Carmin, 1988; Galbraith, 2001; Healy, 1997; Healy \& Welchert, 1990; Mertz, 2004). For instance, Carmin (1988), citing Kram (1980), Levinson (1978), and Parham (1981), suggested that "a mentoring relationship occurs in a learning context and is a continuing, one-to-one relationship between an older and/or more experienced individual and a younger and/or less experienced person" (p. 10). This attempt to define common ground embodies the paradox of putatively universal definitions of mentoring: for some settings they are too broad, while for others they are too narrow. Carmin's definition seems to combine the roles of mentor and counselor, which some have argued are distinct relationships (Mertz, 2004). On the other hand, peer and multiple mentoring (deJanasz \& Sullivan, 2004; Pololi, Knight, Dennis, \& Frankel, 2002) are excluded by the hierarchical and dyadic nature of mentoring in this definition.

Rather than seek a single conception of mentoring, in this chapter we review recent literature on faculty-to-faculty mentoring in higher education (hereafter referred to as "faculty mentoring") to build a conceptual framework that systematically identifies and connects key components of mentoring as reflected in a variety of programs. The framework is analytic and synthetic, not prescriptive or predictive. It captures diverse conceptions of faculty mentoring and is an interpretive structure through which to understand and use this richness in local reinvention of mentoring.

The framework facilitates critical reading of mentoring literature with pointed questions: Who or what is the intended beneficiary? Who or what initiates and sustains mentoring? What is the relationship between the mentor(s) and mentee(s)? What topics do they engage in their interactions? What actions do they take in regard to one another? The framework does not dictate how one ought to conceive of faculty mentoring in any particular setting. Instead, it synthesizes the literature to foreground alternative perspectives on and possibilities for mentoring. As we discuss in the Implications section, the framework can contribute to more effective and purposeful choices in designing, participating in, and evaluating faculty mentoring. 


\section{Methods}

The work that led to this chapter began with what we thought would be a straightforward literature review for an evaluation of a university science faculty mentoring program. We simply wanted to know how others defined mentoring. Reading broadly in foundational literature on mentoring (Allen et al., 2004; Cohen, 1995; Eby, Lockwood, \& Butts, 2006; Kram, 1985; Levinson, 1978) and about mentoring in educational settings (Boice, 1990; Bova, 1995; Luna \& Cullen, 1995; Sands et al., 1991; Wunsch, 1994b), we soon realized that there was no simple answer to our question. In response, we created a provisional conceptual framework for mentoring definitions to identify patterns in the literature. For us, a mentoring definition provides insight into what authors explicitly or implicitly understand mentoring to be. Using a qualitative, groundedtheory approach (Charmaz, 2000; Glaser \& Strauss, 1967), we identified recurrent themes across definitions of mentoring.

We then returned to our initial concern with the nature of faculty mentoring in higher education. Using online databases and reference lists in publications, we narrowed and deepened our literature review to include peer-reviewed articles, edited book chapters, and reports on faculty mentoring in higher education from 1996 to 2007 . We also included a few widely cited publications dating back to the 1980s. We identified eightyeight articles, book chapters, books, and reports for analysis. (A full bibliography is available from the first author.) Moving iteratively between these publications and the provisional framework, we extended and refined the framework to reflect clear patterns in how faculty mentoring is conceptualized in the literature.

\section{Results and Discussion}

The resulting conceptual framework of faculty mentoring contains five dimensions: (1) intended beneficiaries, (2) locus of control, (3) relationship characteristics, (4) topics, and (5) actions. We describe these dimensions with the aid of six diagrams that reflect the range of conceptions of faculty mentoring that we found in the literature. Each diagram is a visual outline that illustrates elements or options within the key dimensions of faculty mentoring identified in our literature review. Lines and arrows in each diagram are organizational tools to represent how one element might be broken into subelements. For example, Figure 3.1, discussed in detail in the following section, depicts the intended beneficiaries of a mentoring relationship. Arrows emanating from the central "intended beneficiaries" box identify these beneficiaries as institutions, groups, and 


\section{Figure 3.I. Intended Beneficiaries in the Mentoring Relationship or Program}

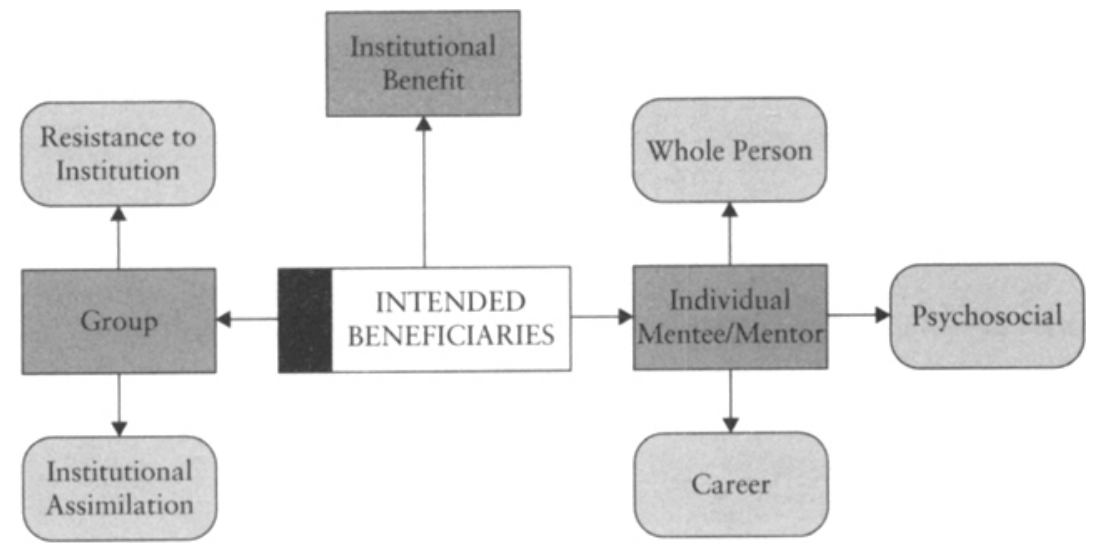

individuals. Further, individuals may be intended to receive career-related or psychosocial benefits, or benefits better described as addressing the whole person.

\section{Intended Beneficiaries}

Certain people, groups, and institutions are intended beneficiaries of faculty mentoring (see Figure 3.1). Mentees, who are usually junior faculty members, are the primary intended beneficiaries (Gray \& Birch, 2007; Luckhaupt et al., 2005; Schrodt, Cawyer, \& Sanders, 2003). Statements about providing “support [for] new faculty" (Reder \& Gallagher, 2007, p. 327) are common in descriptions of the purposes of mentoring. Many mentoring definitions suggest that mentors, who are usually senior faculty, can also benefit from reciprocal mentoring relationships (Gibson, 2004; Jackson et al., 2003; Steiner, Curtis, Lanphear, Vu, \& Main, 2004; Yun \& Sorcinelli, 2009).

Kram (1983, 1985) was the first to describe mentoring as involving both career and psychosocial functions. Henry, Stockdale, Hall, and Deniston (1994) described reciprocal mentoring as involving an exchange of career-related and psychosocial benefits. Intended career-related benefits of academic mentoring include gaining knowledge, improving teaching, acquiring grants, collaborating and networking, developing a research program, publishing, and achieving tenure (St. Clair, 1994). Intended psychosocial benefits include feeling accepted by the academic community, becoming familiar with the campus climate, and receiving social support. Career-related benefits for mentees are the dominant or exclusive focus of 
most faculty mentoring programs and relationships (Berk, Berg, Mortimer, Walton-Moss, \& Yeo, 2005; Hardwick, 2005; Illes, Glover, Wexler, Leung, \& Glazer, 2000; Morzinski, 2005). Faculty mentoring is also intended to provide psychosocial benefits for mentees (Cawyer, Simonds, \& Davis, 2002; deJanasz \& Sullivan, 2004; Snelson et al., 2002). Less frequently, mentoring is seen as a source of psychosocial (Gammack et al., 2004; Morzinski, 2005; Pierce, 1998) and career-related benefits (Campbell, 1992; Smith, Smith, \& Markham, 2000) for mentors. A few articles dissolve the longstanding dualism of career versus psychosocial benefits to describe mentoring in which participants are treated as whole people with intersecting career, psychosocial, and personal worlds (Angelique, Kyle, \& Taylor, 2002; Jordan-Zachery, 2004; McGuire \& Reger, 2003).

Institutional entities (that is, universities, colleges, departments, disciplinary associations) can be the intended beneficiaries of faculty mentoring. Mentoring in these cases is intended to help advance an unspoken contract between institutions and people in which "each expects to give and receive something in the relationship" (Campbell, 1992, p. 75). Institutions may expect mentoring to aid socialization of faculty into organizational culture (Fayne \& Ortquist-Ahrens, 2006; Kirchmeyer, 2005; Snelson et al., 2002), and these institutions may expect to benefit from mentoring by increasing faculty retention (Johnsrud, 1994; Wunsch, 1994b), faculty diversity (Blackwell, 1989; Davidson \& Foster-Johnson, 2001), and scholarly productivity (Bergen \& Connelly, 1988; Mundt, 2001; Olson \& Connelly, 1995).

Groups within institutions are also sometimes conceived as beneficiaries of faculty mentoring. These groups include those who are or have been minorities in academia, including women (Wunsch \& Johnsrud, 1992), African Americans (Green \& King, 2002), and Hispanic women (Bova, 1995). In these instances mentoring is intended to help members of minority groups cope with and challenge inequality in academia (Moody, 2004). This conception sometimes explicitly resists mentoring-as-assimilation and envisions mentoring as a means for participants "to evolve as change agents in the institution" (Angelique et al., 2002, p. 197).

\section{Locus of Control}

Locus of control concerns who has influence over mentoring relationships (see Figure 3.2). In the general literature on mentoring, locus of control is often referenced through the distinction between formal programs (administered by third parties as an institutional program) and informal (managed by mentoring participants) (Chao, Walz, \& Gardner, 1992; Ragins \& Cotton, 1999). Reflecting a pattern in the literature we reviewed, 
Figure 3.2. Locus of Control of the Mentoring Relationship or Program

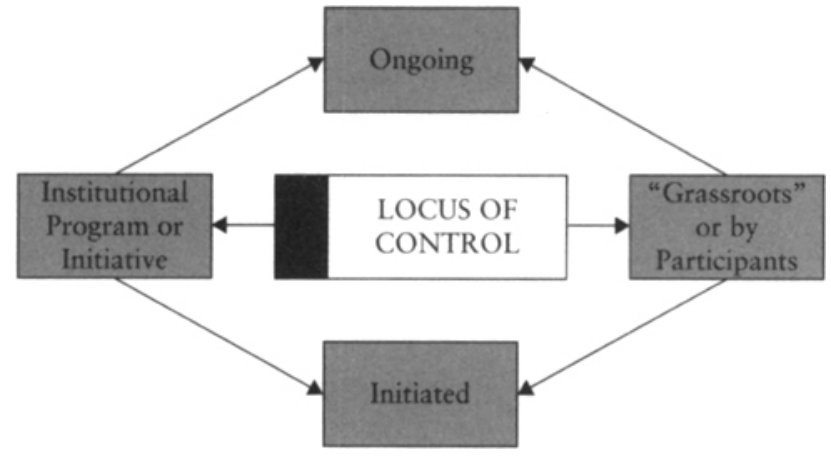

we refine the formal-informal dichotomy by considering who initiates mentoring and who manages it as it proceeds.

In formal mentoring programs, administrators generally have a role in both initiation and ongoing management (Boice, 1990; Lemel \& SullivanCatlin, 2000; Levy et al., 2004; Pololi et al., 2002; Tracy, Jagsi, Starr, \& Tarbell, 2004). There is considerable variation within this generalization. In some cases participants and administrators co-initiate and co-manage mentoring (Gray \& Birch, 2007; Mundt, 2001). Other mentoring programs are so highly structured that they resemble administered faculty development programs (Morzinski, 2005). In practice, many faculty members (including the authors of this chapter) experience formal mentoring when they are assigned a mentor by a supervisor or administrator, and the pair is then left to their own devices to work out the relationship.

In informal mentoring, participants find one another and create relationships. We found few explicit accounts of this kind of mentoring in the literature, though it is a deeply rooted notion of how mentoring develops (cf., Levinson, 1978). One notable example is the New Scholars Network, a program designed and maintained by its participants, not university administrators (Angelique et al., 2002). Morrison-Shetlar and Heinrich (1999); Limbert (1995); and Jacelon, Zucker, Staccarini, and Henneman (2003) describe other mentoring programs that were created and managed by the participants.

\section{Relationship Characteristics}

Relationship characteristics are about the participants and how they interact (see Figure 3.3). The key characteristics we draw from the literature are (1) number of participants, (2) relationship between participants, 
Figure 3.3. Characteristics of the Mentoring Relationship or Program

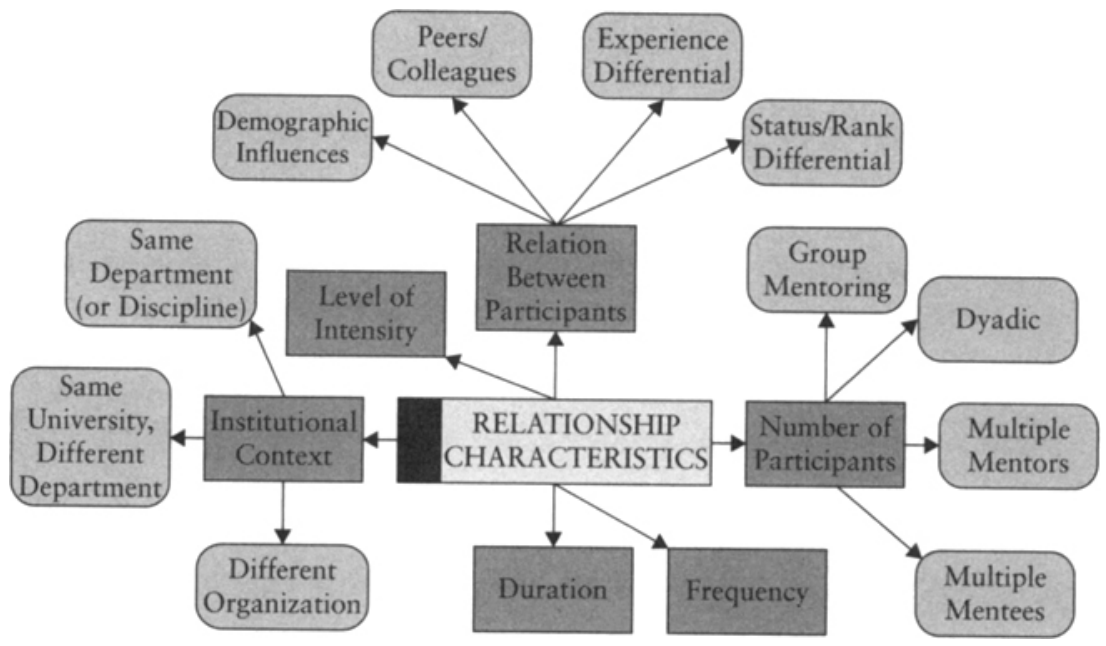

(3) role fluidity, (4) institutional context, (5) level of intensity, (6) frequency, and (7) duration.

NUMBER OF PARTICIPANTS. Mentoring relationships can be dyadic or involve multiple mentors, multiple mentees, or groups. Dyadic mentoring relationships are the most common in the foundational literature on mentoring (Carmin, 1988; Kram, 1980, 1983, 1985; Levinson, 1978). Accounts of faculty mentoring often include explicit statements about the one-on-one, coupled, or paired nature of mentoring, as well as implicit assumptions that two faculty members form the relationship (Boice, 1990; Gibson, 2004; Jackson et al., 2003).

Some scholars suggest that faculty mentees often need multiple mentors simultaneously (Cawyer et al., 2002; Dixon-Reeves, 2003; King \& Cubic, 2005) to "construct a mentoring community based on a diverse set of helpers instead of relying on a single mentor" (Chesler \& Chesler, 2002 , pp. 51-52). Less common are descriptions of one mentor with multiple mentees (Harnish \& Wild, 1994; Levy et al., 2004).

Group mentoring occurs when many faculty members come together to form a mentoring community. Most often this involves junior faculty helping one another as peer mentors (Gammack et al., 2004; Gray \& Birch, 2007; Waitzkin, Yager, Parker, \& Duran, 2006), but it also includes groups of senior and junior faculty members (Cox, 1997; Lemel \& Sullivan-Catlin, 2000). Group mentoring occurs as a stand-alone 
approach (Green \& King, 2002) and in combination with mentor-mentee pairs (Fayne \& Ortquist-Ahrens, 2006).

RELATIONSHIP BETWEEN PARTICIPANTS. The mentoring literature describes mentees, mentors, and their relationship in several ways. Mentees and mentors can differ or be similar to one another in terms of rank, experience, and demographics. Further, mentoring participants might have stable roles as either a mentor or a mentee, or fluid roles that alternate among or combine the characteristics of mentors and mentees.

The most common distinction between mentors and mentees is a difference in rank or tenure (August \& Waltman, 2004; Boice \& Turner, 1989; Smith et al., 2000). Johnsrud (1994) suggested that "mentoring for faculty means coupling those who have been successful in achieving tenure and promotion with those aspiring to reach these traditional milestones for academic achievement" (p. 53). Typically, untenured assistant professors are the population of concern (Girves, Zepeda, \& Gwathmey, 2005; Nielson \& Eisenbach, 2001; Woodd, 2001). Mentors are usually tenured associate or full professors (Fong, 2000; Illes et al., 2000; Lemel \& SullivanCatlin, 2000). Associate professors, it seems, could benefit from mentoring by senior colleagues, but few papers in our sample included associate professors in the target population (Goodwin et al., 2000; Green \& King, 2002; Morrison-Shetlar \& Heinrich, 1999).

Some programs associate mentors' higher rank with achievements in research and teaching (Bergen \& Connelly, 1988; Boice, 1990; Fong, 2000). Others recognize that mentors with "useful experience, knowledge, skills and/or wisdom" (Berk et al., 2005, p. 67) may not be of higher rank than their mentees (Gibson, 2004; Snelson et al., 2002; Woodd, 2001; Yun \& Sorcinelli, 2009). Knowledge may move from a lower to a higher rank, with junior faculty members sharing their experience with more senior members. For example, Morrison-Shetlar and Heinrich (1999) described group mentoring focused on a technique called experiential teaching, in which mentors' pedagogical expertise, not rank, was most important.

In peer mentoring, those of similar rank or status mentor one another, exchanging experiences, ideas, and concerns (Chesler \& Chesler, 2002; deJanasz \& Sullivan, 2004). In this approach, individuals play multiple and fluid roles as both mentors and mentees (Harnish \& Wild, 1993; McGuire \& Reger, 2003). Peer mentoring usually occurs in groups (Angelique et al., 2002; Benson, Morahan, Sachdeva, \& Richman, 2002; Pololi et al., 2002), and peer mentors are often included among the multiple mentors had by mentees (Grant \& Ward, 1992; Lewellen-Williams et al., 2006; Woodd, 2001). 
Conceptions of mentoring may also be shaped by concerns about the demographic characteristics of participants. Studies of demographic factors in mentoring have examined the experiences of minorities and women (Bova, 1995; Solorzano, 1998; Tillman, 2001) and compared the outcomes of homogeneous (by sex and minority status) and heterogeneous mentoring relationships (Boice, 1990; Boice \& Turner, 1989; Smith et al., 2000). Some mentoring programs have been designed exclusively for women and minorities (Green \& King, 2002; Jordan-Zachery, 2004; Wunsch \& Johnsrud, 1992). Many of these use peer mentoring to deemphasize power differentials (McGuire \& Reger, 2003) or build empathic communities of support (Chesler \& Chesler, 2002; Green \& King, 2002). Programs for general faculty populations have been designed to address similar concerns by pairing mentors and mentees of the same sex (Lemel \& Sullivan-Catlin, 2000), and by encouraging mentors to be sensitive to the particular challenges faced by women and minorities (Fong, 2000; King \& Cubic, 2005; Waitzkin et al., 2006).

INSTITUTIONAL CONTEXT. Most mentoring programs are interdepartmental (Fong, 2000; Lemel \& Sullivan-Catlin, 2000; Reder \& Gallagher, 2007) or include both intra- and interdepartmental relationships (Cox, 1997; Gray \& Birch, 2007; Hardwick, 2005). Although many faculty members encounter intradepartmental mentoring, few exclusively intradepartmental programs are described in the literature we examined (Tracy et al., 2004). The putative benefits of intradepartmental mentoring include "ease of daily contact" (Hardwick, 2005, p. 24) and the ability to provide "concrete guidance that is specific to the discrete unit" (Borisoff, 1998 , p. 87). Interdepartmental mentoring may be motivated by a limited pool of mentors in a department (Herr, 1994), or by the belief that mentees may be better able to share frustrations and failures with mentors outside their departments (Fayne \& Ortquist-Ahrens, 2006).

Cross-institutional mentoring generally aims to connect mentees and mentors who are in the same discipline or demographic group. The External Mentor Program described by Mundt (2001) sought out external mentors with strong research records in mentees' areas of study to help the mentees increase their research productivity. Other mentoring programs have spanned institutional boundaries to link biomedical scholars and leaders (King \& Cubic, 2005; Lewellen-Williams et al., 2006), geographers (Hardwick, 2005), and ethnic minorities (Waitzkin et al., 2006). Cross-institutional mentoring also happens when faculty members maintain mentoring relationships that were established earlier in their career at other institutions (Grant \& Ward, 1992; Kirchmeyer, 2005). 
LEVEL OF INTENSITY. Mentoring relationships vary in intensity (Kirchmeyer, 2005), but accounts in the literature either do not explicitly address intensity or suggest that mentoring ought to be a markedly intense experience for all participants. In favor of high-intensity relationships, Campbell (1992) suggests that faculty mentoring is "not for the timid or casual" (p. 77), and Pierce (1998) states that mentors ought to be "the most personal and intimate point of contact that the new faculty member has with the organization" (p. 9). Others suggest that faculty mentoring involves trust (Blackwell, 1989), intense exchange (Smith et al., 2000), genuine caring and concern for mentees' well-being (Chalmers, 1992; Gibson, 2004; Snelson et al., 2002), nurturing and protection (Girves et al., 2005), and creation of a home place (hooks, 1989) in which faculty are safe and free from marginalization (Jordan-Zachery, 2004).

DURATION AND FREQUENCY. Some descriptions of mentoring refer to its duration and frequency. Authors often treat duration as a continuum, ranging from short- to long-term, having no distinct end point, and being determined by the needs of the participants (Berk et al., 2005; Gammack et al., 2004; Hardwick, 2005). Luckhaupt and colleagues (2005) suggest that mentoring should continue "over an extended period of time" (p. 1015), and Souba (1999) describes most "worthy" mentoring relationships as “infrequently short-term" (p. 113). Mentoring programs typically specify a minimum length of participation, from four months to six years, beyond which participants may choose to continue the relationship (Fox, Waldron, Bohnert, Hishinuma, \& Nordquist, 1998; Golding \& Gray, 2002; Mundt, 2001).

Like duration, prescriptions for the frequency of mentoring interactions vary widely. Accounts that address this issue suggest that participants meet frequently (Benson et al., 2002; Boice, 1990; Mundt, 2001), specify just how frequently participants are expected to meet (Illes et al., 2000; Limbert, 1995; Pololi, Knight, \& Dunn, 2004), or leave it to participants to decide (Chesler \& Chesler, 2002; Wunsch \& Johnsrud, 1992). Programs that call for frequent meetings seem to favor once per week (Boice, 1990; Golding \& Gray, 2002; Green \& King, 2002).

\section{Topics}

In the literature we reviewed, the most important topics (see Figure 3.4) for mentors and mentees to address are how to balance research, teaching, and service; and how to navigate the politics and procedures of academia on the way to promotion and tenure (Angelique et al., 2002; Benson et al., 
Figure 3.4. Topics of Focus in the Mentoring Relationship or Program

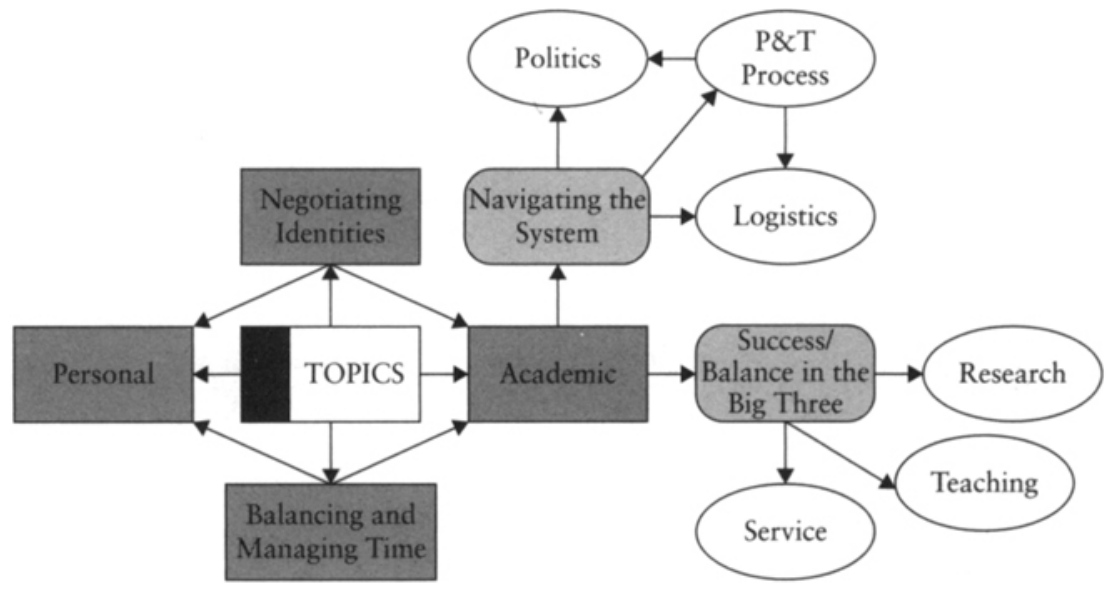

2002; Gray \& Birch, 2007). Some faculty mentoring programs focus more on teaching (Chism, Fraser, \& Arnold, 1996; Golding \& Gray, 2002; Reder \& Gallagher, 2007) or research (Jacelon et al., 2003; Mundt, 2001; Waitzkin et al., 2006). Service was included as part of the larger concern about time management and workload (Fayne \& Ortquist-Ahrens, 2006; Hardwick, 2005; Smith et al., 2001).

Personal issues are also a common topic in accounts of faculty mentoring (Chalmers, 1992; Fox et al., 1998; Jordan-Zachery, 2004). Campbell (1992) wrote: "No one will be surprised that mentoring includes reviewing drafts of manuscripts or revising the design of a research project; less obvious is that mentoring can include dealing with terminal illness, unplanned pregnancy, and financial distress" (p. 77).

The challenges of balancing personal concerns and academic life are addressed in many conceptions of faculty mentoring (King \& Cubic, 2005; Levy et al., 2004; McGuire \& Reger, 2003). Some authors suggest that faculty mentoring is part of negotiating personal and professional identities (Jordan-Zachery, 2004; Tillman, 2001; Wunsch \& Johnsrud, 1992) and thus includes exploring such issues as what it means to be both a Hispanic woman and an academic (Bova, 1995).

\section{Actions}

The final dimension in our conceptual framework of faculty mentoring is about what mentors and mentees do in mentoring relationships (see Figures 3.5 and 3.6). We avoid using the broad terms for mentoring roles 
Figure 3.5. Mentor Actions in the Mentoring Relationship or Program

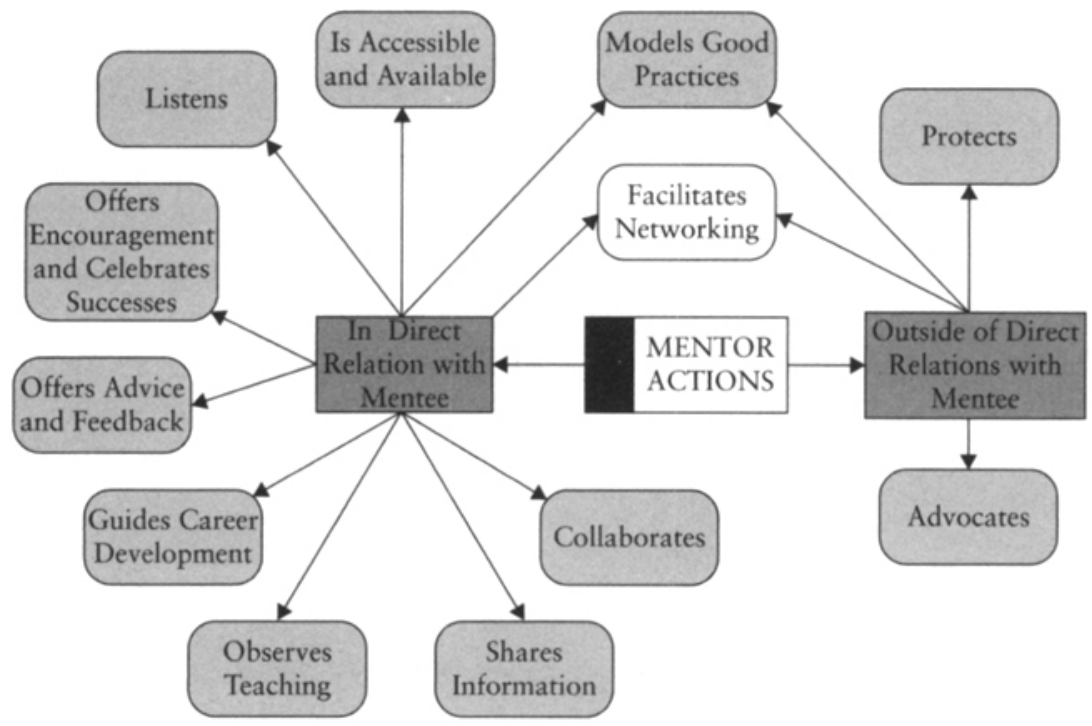

Figure 3.6. Mentee Actions in the Mentoring Relationship or Program

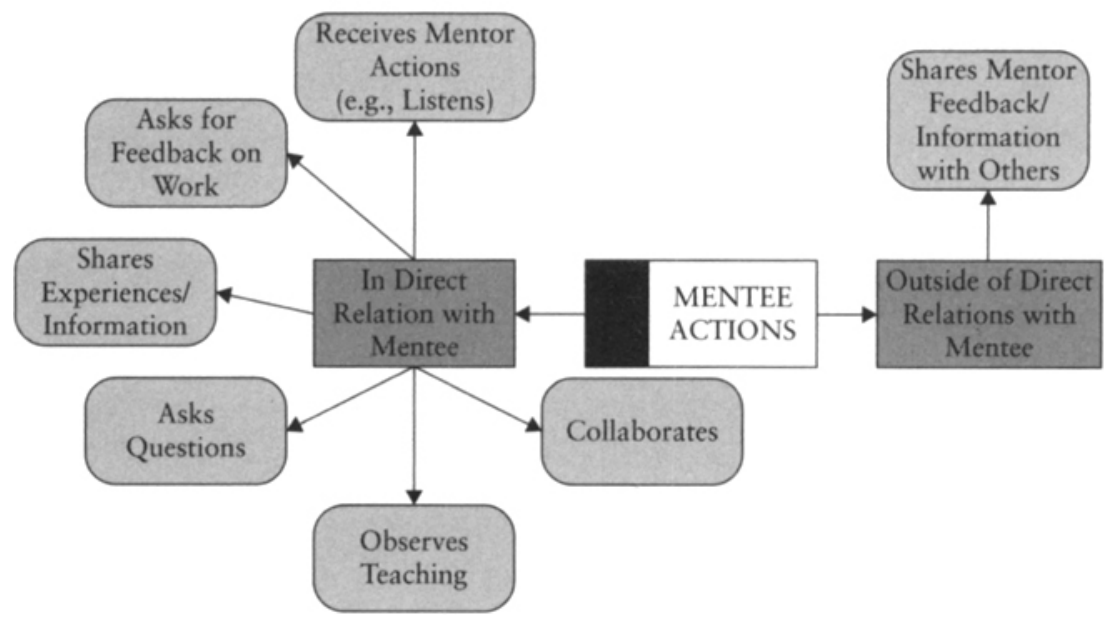

that are common in the literature, such as teacher or counselor, and instead focus on concrete actions.

MENTOR ACTIONS. In most accounts, mentors have the active, causal role in the relationship. Mentors can interact directly with mentees or take 
actions with other people that indirectly affect mentees (see Figure 3.5). In direct interactions with mentees, mentors make themselves available (Lemel \& Sullivan-Catlin, 2000; Pierce, 1998; Souba, 1999), listen (Angelique et al., 2002; Borisoff, 1998; Fox et al., 1998), offer encouragement and celebrate successes (Berk et al., 2005; Blackwell, 1989; Smith et al., 2001), give advice and feedback on specific work and ideas (Jacelon et al., 2003; King \& Cubic, 2005; Lewellen-Williams et al., 2006) or overall career development (Benson et al., 2002; Morzinski, 2005; Sands et al., 1991), observe mentees' teaching (Golding \& Gray, 2002; St. Clair, 1994), share information (Dixon-Reeves, 2003; Limbert, 1995; Souba, 1999), and collaborate with mentees (Goodwin et al., 2000; Pololi et al., 2004; Reder \& Gallagher, 2007). Working indirectly, mentors may facilitate networking with or on behalf of mentees (Gammack et al., 2004; King \& Cubic, 2005; Mundt, 2001); model good teaching, research, and service practices (Bova, 1995; Dixon-Reeves, 2003; Golding \& Gray, 2002); protect mentees from being overloaded with extraneous obligations (Girves et al., 2005; Sands et al., 1991; Snelson et al., 2002); and advocate on behalf of mentees (Borisoff, 1998; Lewellen-Williams et al., 2006; Wunsch \& Johnsrud, 1992).

MENTEE ACTIONS. Descriptions of mentoring address mentor actions more than mentee actions (Blackwell, 1989; Goodwin \& Stevens, 1998; Knox \& McGovern, 1988). Perhaps this is not surprising for an activity called mentoring, but mentoring is also conceived as an interaction among participants. The mentee action we call "receiving mentor actions" (see Figure 3.6) could include listening to and engaging mentors' advice. Some authors offer a more complex picture of actions entailed in being a mentee, repositioning mentees from passive recipients to "agents in their own development" (Yun \& Sorcinelli, 2009, p. 369). In direct interactions with mentors, mentees may share their experiences, ask for feedback on work, and pass along information (Jacelon et al., 2003; Morrison-Shetlar \& Heinrich, 1999; Pololi et al., 2002); ask questions (Benson et al., 2002; Jacelon et al., 2003; St. Clair, 1994); observe mentors' classes (Golding \& Gray, 2002; Lemel \& Sullivan-Catlin, 2000); collaborate with mentors (Goodwin et al., 2000; Pololi et al., 2004; Reder \& Gallagher, 2007); and participate in networking facilitated by the mentor (Benson et al., 2002). Beyond face-to-face interactions with their mentors, mentees may extend mentoring relationships by sharing what they have gained with others. For example, mentees in hierarchical, dyadic mentoring relationships can use peer mentoring to share experiences and reflect on challenges with one another (Gray \& Birch, 2007). 


\section{Implications}

Wunsch (1994a) cautioned that those involved in faculty mentoring programs "will get little conclusive guidance about definitions from the literature or from observing working programs" (p. 28). Our framework is meant to help those who administer, participate in, and evaluate mentoring programs thoughtfully consider key dimensions of mentoring that emerge from published accounts. Because the framework reflects diverse conceptions of faculty mentoring, it can inform design decisions in very different kinds of approaches. For example, a grassroots group of junior faculty members could use the framework to envision group peer mentoring as a way to help one another cope with the entangled responsibilities of their professional and personal lives. But the framework also reflects the characteristics of institutionally administered mentoring programs that connect senior and junior faculty members to help junior colleagues achieve promotion and tenure.

We developed a worksheet (see Exhibit 3.1) to help mentoring program developers, participants, and evaluators use the framework in Figures 3.1 through 3.6. The worksheet leads users through key issues and the range of responses that we found in the literature we reviewed. Additional space is provided for novel responses and adaptations of the framework. The worksheet does not prescribe what mentoring programs ought to look like. Instead, it organizes the diverse ways that faculty mentoring has been conceptualized, making it easier, hopefully, for those involved in mentoring to thoughtfully consider a variety of possibilities. Depending on the context in which the worksheet is applied, some of the questions will be more relevant than others.

The worksheet may be used differently by mentoring program developers, participants, and evaluators. Mentoring program developers and administrators can use it to think systematically about program design. For example, the lead author's department chair asked her to develop a proposal for a departmental mentoring program to help first- and second-year faculty enhance their teaching. She used the worksheet to sketch out key characteristics of such a program (see Exhibit 3.2). If used by participants, the worksheet offers prompts for critical reflection about what mentees and mentors want to make of their relationships. The worksheet might help them uncover assumptions so they can more explicitly consider what they want to gain from the experience and what they are willing to contribute to it. Evaluators can adapt the worksheet to characterize what mentoring experiences are like in practice, in comparison to the intentions of programs and participants. For instance, in evaluating the science faculty mentoring 


\section{Exhibit 3.I. Faculty Mentoring Program Worksheet}

Question

1. How many participants are there in the mentoring relationship?

2. How are these participants related to one another with respect to rank, experience, and status?

3. To what extent are participants intentionally matched with respect to demographic characteristics?

4. How are mentoring participants related with respect to the institutional context?

5. Who stands to benefit from mentoring?

\section{Response(s): Check all that apply}

$\square$ One mentee with one mentor (dyadic)

$\square$ One mentee with multiple mentors

$\square$ One mentor with multiple mentees

$\square$ A group in which individuals mentor one another $\square$ Other:

$\square$ Difference in rank, specifically: (e.g., mentor is associate professor or higher, and mentee is assistant professor)

$\square$ Difference in experience, specifically: (e.g., teaching)

Similar status as peers/colleagues, specifically: Other: (e.g., associate professors)

$\square$ Demographic similarity of participants, specifically, (e.g., same sex), is:

$\square$ required

preferred

$\square$ not a matter of consideration

Other:

$\square$ In the same department:

$\square$ In the same university/college, but in different departments, specifically:

$\square$ In different universities/institutions, specifically:

\section{Other:}

Individuals:

$\square$ mentees, who benefit by

$\square$ mentors, who benefit by

$\square$ other:

Institution, specifically

(e.g., university, college, department) that benefits by

Group, having this defining characteristic: (e.g., women), benefits by

Other:

6. What is the scope of individual benefit?
Career benefits are the primary focus

$\square$ Career and psychosocial benefits

$\square$ The whole person and his or her needs will be attended to

Other: 


\section{Exhibit 3.I. (Continued)}

\section{Question}

7. Who is responsible for initiating the mentoring relationship(s)?
Response(s): Check all that apply

Individual participants, namely:

$\square$ mentees

$\square$ mentors

$\square$ the group

The institutional program/initiative (i.e., those other than participants), namely:

Other:
8. Who is responsible for ongoing management and control of mentoring relationship(s)?

9. How often do participants interact?

10. How long does the relationship last?

11. How would the intensity of an ideal mentoring relationship be described?

12. What are the major topics to be addressed in the mentoring relationship?
Individual participants, namely:

$\square$ mentees

$\square$ mentors

$\square$ the group

The institutional program/initiative (i.e., those other than participants), namely:

Other:

Face-to-face meetings:

(e.g., once per month)

Electronic/phone contact:

(e.g., as needed)

Duration:

(e.g., for one year)

$\square$ Casual

$\square$ Caring, involving genuine concern

$\square$ Other:

Success in (check all that apply):

$\square$ Research

$\square$ Teaching

$\square$ Service

$\square$ Balance among/between some combination of the above:

Navigating the system, specifically:

$\square$ Promotion and tenure process (i.e., logistics and politics)

$\square$ Other logistics, specifically:

department) (e.g., navigating the

$\square$ Politics

Balancing personal/academic responsibilities and managing demands on personal/academic time 
$\square$ Negotiating personal/academic identities, specifically: Hispanic faculty member) (e.g., being a

Other:

13. What does a mentor do?

$\square$ ls accessible and
available
$\square$ Listens
$\square$ Offers encouragement
$\square$ Celebrates success
$\square$ Guides career devel-
opment
$\square$ Observes teaching
$\square$ Shares information
$\square$ Offers advice and feed-
back
$\square$ Collaborates
$\square$ Models good practices
$\square$ Facilitates networking
$\square$ Protects
$\square$ Advocates

Space to elaborate checked items and add others:

14. What does a mentee do?
Asks for feedback on work
$\square$ Shares experiences/ information
$\square$ Asks questions
$\square$ Observes teaching
$\square$ Collaborates
$\square$ Shares feedback with others

Space to elaborate checked items and add others:

\section{Exhibit 3.2. Using the Faculty Mentoring Program Worksheet}

\section{Question}

No. of participants

Experience, rank, status difference?

Demographics

\section{Response(s)}

One mentee with multiple (two to three) mentors

$\square$ Difference in experience, specifically pedagogical or pedagogical content knowledge (PCK)

Note: likely to be of different rank, but that is not as important as experience

Demographic similarity among participants, specifically, same sex or ethnic minority status is: $\square$ preferred (i.e., will try to find demographically similar mentors for mentees)

(Continued) 


\section{Exhibit 3.2. (Continued)}

$\begin{array}{ll}\text { Question } & \text { Response(s) } \\ \begin{array}{l}\text { Institutional } \\ \text { context }\end{array} & \square \text { In the same department }\end{array}$

Beneficiaries $\square$ Mentees who benefit by learning from experienced teachers, and improving pedagogical and PCK (primary beneficiary)

$\square$ Mentors who benefit by learning from other mentors, the mentee, and self-reflection (improve pedagogical knowledge and PCK)

$\square$ Institution, specifically the department, which benefits from higher quality teaching

Scope of indi-

$\square$ Career and psychosocial benefits (teaching is inherently psychosocial endeavor)

Initiation of relationship

The institutional program (those other than participants); department chair and program developer recruit teaching mentors

Ongoing management of relationship

Frequency of interaction

\section{Duration}

Intensity

Topics

What does a mentor do?
Individual participants, that is, $\square$ mentees and $\square$ mentors, who communicate flexibly (in addition to required activities) $\square$ The institutional program (those other than participants), requires certain activities (for example, face-to-face meetings, teaching observations; see frequency secrion)

Face-to-face meetings: twice each semester (minimum)

Electronic/phone contact: as needed

Teaching observations: mentee is observed by mentors in second year; mentee observes mentors once each semester in first and second year

Two years (first and second year for mentee) and beyond as desired by participants

$\square$ Caring, involving, genuine concern for mentees' and students' success

Success in $\square$ teaching and in $\square$ balancing teaching and other responsibilities

Is accessible and available "Collaborates" refers to work-

Listens

Offers encouragement

Celebrates success

Observes teaching

$\square$ Shares information ing together to enact pedagogical ideas; collaboration may continue into the future; sharing information includes syllabi, activities, demonstrations, ideas, etc. 


\begin{tabular}{|c|c|c|c|}
\hline \multirow{9}{*}{$\begin{array}{l}\text { What does a } \\
\text { mentee do? }\end{array}$} & 口 & $\begin{array}{l}\text { Offers advice and feed- } \\
\text { back }\end{array}$ & \multirow{9}{*}{$\begin{array}{l}\text { "Collaborates" refers to work- } \\
\text { ing together to enact peda- } \\
\text { gogical ideas; collaboration may } \\
\text { continue into the future }\end{array}$} \\
\hline & $\nabla$ & Models good practices & \\
\hline & $\nabla$ & Facilitates networking & \\
\hline & $\square$ & Collaborates & \\
\hline & 口 & $\begin{array}{l}\text { Asks for feedback on } \\
\text { work }\end{array}$ & \\
\hline & $\nabla$ & $\begin{array}{l}\text { Shares experiences/ } \\
\text { information }\end{array}$ & \\
\hline & $\square$ & Asks questions & \\
\hline & 口 & Observes teaching & \\
\hline & $\nabla$ & Collaborates & \\
\hline
\end{tabular}

program that motivated this literature review, we discovered highly variable understandings and manifestations of mentoring rooted in a weakly conceptualized program. The leaders of the program have since directed more attention to developing a shared vision of mentoring by considering some of the issues identified in the conceptual framework and the worksheet. In this way, we hope the conceptual framework we have presented will contribute to more successful mentoring experiences across the diverse settings of higher education.

\section{REFERENCES}

Allen, T. D., Eby, L. T., Poteet, M. L., Lentz, E., \& Lima, L. (2004). Career benefits associated with mentoring for protégés: A meta-analysis. Journal of Applied Psychology, 89(1), 127-136.

Angelique, H., Kyle, K., \& Taylor, E. (2002). Mentors and muses: New strategies for academic success. Innovative Higher Education, 26(3), 195-209.

August, L., \& Waltman, J. (2004). Culture, climate, and contribution: Career satisfaction among female faculty. Research in Higher Education, 45(2), 177-191.

Benson, C. A., Morahan, P. S., Sachdeva, A. K., \& Richman, R. C. (2002). Effective faculty preceptoring and mentoring during reorganization of an academic medical center. Medical Teacher, 24(5), 550-557.

Bergen, D., \& Connelly, J. (1988). The collegial research mentor project: A model for faculty research and scholarship development. Career Planning and Adult Development Journal, 4(2), 3-8. 
Berk, R. A., Berg, J., Mortimer, R., Walton-Moss, B., \& Yeo, T. P. (2005). Measuring the effectiveness of faculty mentoring relationships. Academic Medicine, 80(1), 66-71.

Blackwell, J. E. (1989). Mentoring: An action strategy for increasing minority faculty. Academe, 75(5), 8-14.

Boice, R. (1990). Mentoring new faculty: A program for implementation. Journal of Staff, Program, and Organizational Development, 8(3), 143-160.

Boice, R., \& Turner, J. L. (1989). The FIPSE-CSULB mentoring project for new faculty. In S. Kahn (Ed.), To improve the academy: Vol. 8. Resources for student, faculty, and institutional development (pp. 117-129). Stillwater, OK: New Forums Press.

Borisoff, D. (1998). Strategies for effective mentoring and for being effectively mentored: A focus on research institutions. Journal of the Association for Communication Administration, 27(2), 84-96.

Bova, B. M. (1995). Mentoring revisited: The Hispanic woman's perspective. MPAEA Journal of Adult Education, 23(1), 8-19.

Campbell, W. H. (1992). Mentoring of junior faculty. American Journal of Pharmaceutical Education, 56(1), 75-79.

Carmin, C. N. (1988). Issues in research on mentoring: Definitional and methodological. International Journal of Mentoring, 2(2), 9-13.

Cawyer, C. S., Simonds, C., \& Davis, S. (2002). Mentoring to facilitate socialization: The case of the new faculty member. Qualitative Studies in Education, 15(2), 225-242.

Chalmers, R. K. (1992). Faculty development: The nature and benefits of mentoring. American Journal of Pharmaceutical Education, 56(1), 71-74.

Chao, G. T., Walz, P. M., \& Gardner, P. D. (1992). Formal and informal mentorships: A comparison on mentoring functions and contrast with nonmentored counterparts. Personnel Psychology, 45(3), 619-636.

Charmaz, K. (2000). Grounded theory: Objectivist and constructivist methods. In N. K. Denzin \& Y. S. Lincoln (Eds.), Handbook of qualitative research (2nd ed., pp. 509-536). Thousand Oaks, CA: Sage.

Chesler, N. C., \& Chesler, M. A. (2002). Gender-informed mentoring strategies for women engineering scholars: On establishing a caring community. Journal of Engineering Education, 91(1), 49-55.

Chism, N.V.N., Fraser, J. M., \& Arnold, R. L. (1996). Teaching academies: Honoring and promoting teaching through a community of expertise. In R. J. Menges \& M. D. Svinicki (Eds.), New directions for adult and continuing education: No. 65. Honoring exemplary teaching (pp. 25-32). San Francisco: Jossey-Bass.

Cohen, N. H. (1995). The principles of adult mentoring scale. In M. W. Galbraith \& N. H. Cohen (Eds.), New directions for adult and continuing education: 
No. 66. Mentoring: New strategies and challenges (pp. 15-32). San Francisco: Jossey-Bass.

Cox, M. D. (1997). Long-term patterns in a mentoring program for junior faculty: Recommendations for practice. In D. Dezure (Ed.), To improve the academy: Vol. 16. Resources for faculty, instructional, and organizational development (pp. 225-268). Stillwater, OK: New Forums Press.

Davidson, M. N., \& Foster-Johnson, L. (2001). Mentoring in the preparation of graduate researchers of color. Review of Educational Research, 71(4), 549-574.

deJanasz, S. C., \& Sullivan, S. E. (2004). Multiple mentoring in academe: Developing the professional network. Journal of Vocational Behavior, 64(2), 263-283.

Dixon-Reeves, R. (2003). Mentoring as a precursor to incorporation: An assessment of the mentoring experience of recently minted Ph.D.s. Journal of Black Studies, 34(1), 12-27.

Eby, L. T., Lockwood, A. L., \& Butts, M. (2006). Perceived support for mentoring: A multiple perspectives approach. Journal of Vocational Behavior, 68(2), 267-291.

Fayne, H., \& Ortquist-Ahrens, L. (2006). Learning communities for first-year faculty: Transition, acculturation, and transformation. In S. ChadwickBlossey \& D. R. Robertson (Eds.), To improve the academy: Vol. 24. Resources for faculty, instructional, and organizational development (pp. 277-290). Bolton, MA: Anker.

Fong, B. (2000). Toto, I think we're still in Kansas: Supporting and mentoring minority faculty and administrators. Liberal Education, 86(4), 56-60.

Fox, E. C., Waldron, J. A., Bohnert, P., Hishinuma, E. S., \& Nordquist, C. R. (1998). Mentoring new faculty in a department of psychiatry. Academic Psychiatry, 22(2), 98-106.

Galbraith, M. W. (2001). Mentoring development for community college faculty. Michigan Community College Joumal of Research and Practice, 7(2), 29-39.

Gammack, J. K., Rudolph, J. L., Adedokun, A., Hirth, V., Kevorkian, R., \& Misra, S. (2004). Perceptions of geriatric medicine junior faculty on success in academic medicine: The Saint Louis University Geriatric Academy (SLUGA) Faculty Development Program. Journals of Gerontology Series A: Biological Sciences and Medical Sciences, 59(10), M1029-M1035.

Gibson, S. K. (2004). Being mentored: The experience of women faculty. Journal of Career Development, 30(3), 173-188.

Girves, J. E., Zepeda, Y., \& Gwathmey, J. K. (2005). Mentoring in a postaffirmative action world. Journal of Social Issues, 61(3), 449-479.

Glaser, B., \& Strauss, A. (1967). The discovery of grounded theory. Hawthorne, NY: Aldine de Gruyter. 
Golding, T. L., \& Gray, E. D. (2002). Mentoring mathematics faculty: A model. Primus, 12(1), 87-95.

Goodwin, L. D., \& Stevens, E. A. (1998). An exploratory study of the role of mentoring in the retention of faculty. Journal of Staff, Program, and Organizational Development, 16(1), 39-47.

Goodwin, L. D., Stevens, E. A., Goodwin, W. L., \& Hagood, E. A. (2000). The meaning of faculty mentoring. Journal of Staff, Program, and Organizational Development, 17(1), 17-30.

Grant, L., \& Ward, K. B. (1992). Mentoring, gender, and publication among social, natural, and physical scientists. Final report. Washington, DC: Office of Educational Research and Improvement.

Gray, T., \& Birch, A. J. (2007). Team mentoring: An alternative way to mentor new faculty. In D. R. Robertson \& L. B. Nilson (Eds.), To improve the academy: Vol. 26. Resources for faculty, instructional, and organizational development (pp. 230-241). Bolton, MA: Anker.

Green, C. E., \& King, V. G. (2002). Sisters mentoring sisters: Africentric leadership development for black women in the academy. Journal of Negro Education, 70(3), 156-165.

Hardwick, S. W. (2005). Mentoring early career faculty in geography: Issues and strategies. Professional Geographer, 57(1), 21-27.

Harnish, D., \& Wild, L. A. (1993). Peer mentoring in higher education: A professional development strategy for faculty. Community College Journal of Research and Practice, 17(3), 271-282.

Harnish, D., \& Wild, L. A. (1994). Mentoring strategies for faculty development. Studies in Higher Education, 19(2), 191-201.

Healy, C. C. (1997). An operational definition of mentoring. In H. T. Frierson, Jr. (Ed.), Diversity in higher education: Mentoring and diversity in higher education (Vol. 1, pp. 9-22). Greenwich, CT: JAI Press.

Healy, C. C., \& Welchert, A. J. (1990). Mentoring relations: A definition to advance research and practice. Educational Researcher, 19(9), 17-21.

Henry, J. S., Stockdale, M. B., Hall, M., \& Deniston, W. (1994). A formal mentoring program for junior female faculty: Description and evaluation. Initiatives, 56(2), 37-45.

Herr, K. U. (1994). Mentoring faculty at the department level. In M. A. Wunsch (Ed.), New directions for teaching and learning: Vol. 57. Mentoring revisited: Making an impact on individuals and institutions (pp. 81-90). San Francisco: Jossey-Bass.

hooks, b. (1989). Talking back: Thinking feminist, thinking black. Boston: South End Press.

Illes, J., Glover, G. H., Wexler, L., Leung, A.N.C., \& Glazer, G. M. (2000). A model for faculty mentoring in academic radiology. Academic Radiology, 7(9), 717-724. 
Jacelon, C. S., Zucker, D. M., Staccarini, J.-M., \& Henneman, E. A. (2003). Peer mentoring for tenure-track faculty. Journal of Professional Nursing, 19(6), 335-338.

Jackson, V. A., Palepu, A., Szalacha, L., Caswell, C., Carr, P. L., \& Inui, T. (2003). "Having the right chemistry": A qualitative study of mentoring in academic medicine. Academic Medicine, 78(3), 328-334.

Johnsrud, L. K. (1994). Enabling the success of junior faculty women through mentoring. In M. A. Wunsch (Ed.), New directions for teaching and learning: Vol. 57. Mentoring revisited: Making an impact on individuals and institutions (pp. 53-63). San Francisco: Jossey-Bass.

Jordan-Zachery, J. S. (2004). Reflections on mentoring: Black women and the academy. PS: Political Science and Politics, 37(4), 875-877.

King, C. A., \& Cubic, B. (2005). Women psychologists within academic health systems: Mentorship and career advancement. Journal of Clinical Psychology in Medical Settings, 12(3), 271-280.

Kirchmeyer, C. (2005). The effects of mentoring on academic careers over time: Testing performance and political perspectives. Human Relations, 58(5), 637-660.

Knox, P. L., \& McGovern, T. V. (1988). Mentoring women in academia. Teaching of Psychology, 15(1), 39-41.

Kram, K. E. (1980). Mentoring process at work: Developmental relationships in managerial careers. Unpublished doctoral dissertation, Yale University, New Haven, CT.

Kram, K. E. (1983). Phases of the mentor relationship. Academy of Management Journal, 26(4), 608-625.

Kram, K. E. (1985). Mentoring at work: Developmental relationships in organizational life. Glenview, IL: Scott, Foresman.

Lemel, R., \& Sullivan-Catlin, H. (2000). The Kean University mentoring program: A model for integrating new faculty. Journal of Staff, Program, and Organizational Development, 17(1), 51-55.

Levinson, D. J. (1978). The seasons of a man's life. New York: Knopf.

Levy, B. D., Katz, J. T., Wolf, M. A., Sillman, J. S., Handin, R. I., \& Dzau, V. J. (2004). An initiative in mentoring to promote residents' and faculty members' careers. Academic Medicine, 79(9), 845-850.

Lewellen-Williams, C., Johnson, V. A., Deloney, L. A., Thomas, B. R., Goyol, A., \& Henry-Tillman, R. (2006). The POD: A new model for mentoring underrepresented minority faculty. Academic Medicine, 81(3), 275-279.

Limbert, C. A. (1995). Crysalis, a peer mentoring group for faculty and staff women. NWSA Journal, 7(2), 86-99.

Luckhaupt, S. E., Chin, M. H., Mangione, C. M., Phillips, R. S., Bell, D., Leonard, A. C., et al. (2005). Mentorship in academic general internal medicine. Journal of General Internal Medicine, 20(11), 1014-1018. 
Luna, G., \& Cullen, D. L. (1995). Empowering the faculty: Mentoring redirected and renewed (ASHE-ERIC Higher Education Report No. 3). Washington, DC: George Washington University, Graduate School of Education and Human Development.

McGuire, G. M., \& Reger, J. (2003). Feminist co-mentoring: A model for academic professional development. NWSA Journal, 1S(1), 54-72.

Mertz, N. T. (2004). What's a mentor anyway? Educational Administration Quarterly, 40(4), 541-560.

Moody, J. (2004). Faculty diversity: Problems and solutions. New York: RoutledgeFalmer.

Morrison-Beedy, D., Aronowitz, T., Dyne, J., \& Mkandawire, L. (2001). Mentoring students and junior faculty in faculty research: A win-win scenario. Journal of Professional Nursing, 17(6), 291-296.

Morrison-Shetlar, A., \& Heinrich, K. T. (1999). Mentoring at the edge: A faculty group fosters experiential teaching. Journal of Experiential Education, 22(1), 5-11.

Morzinski, J. A. (2005). Mentors, colleagues, and successful health science faculty: Lessons from the field. Journal of Veterinary Medical Education, 32(1), 5-11.

Mundt, M. H. (2001). An external mentor program: Stimulus for faculty research development. Journal of Professional Nursing, 17(1), 40-45.

Nielson, T. R., \& Eisenbach, R. J. (2001). Mentoring in academia: A conversation with Lyman Porter. Journal of Management Inquiry, 10(2), 183-189.

Olson, R. K., \& Connelly, L. M. (1995). Mentoring through predoctoral fellowships to enhance research productivity. Journal of Professional Nursing, $11(5), 270-275$.

Parham, W. D. (1981). Mentors and protégés: Stages of development in a mentoring relationship. Unpublished doctoral dissertation, Southern Illinois University, Carbondale.

Pierce, G. (1998). Developing new university faculty through mentoring. Journal of Humanistic Education and Development, 37(1), 13-40.

Pololi, L. H., Knight, S. M., Dennis, K., \& Frankel, R. M. (2002). Helping medical school faculty realize their dreams: An innovative, collaborative mentoring program. Academic Medicine, 77(5), 377-384.

Pololi, L. H., Knight, S., \& Dunn, K. (2004). Facilitating scholarly writing in academic medicine: Lessons learned from a collaborative peer mentoring program. Journal of General Internal Medicine, 19(1), 64-68.

Ragins, B. R., \& Cotton, J. L. (1999). Mentor functions and outcomes: A comparison of men and women in formal and informal mentoring relationships. Journal of Applied Psychology, 84(4), 529-550. 
Reder, M., \& Gallagher, E. V. (2007). Transforming a teaching culture through peer mentoring: Connecticut College's Johnson Teaching Seminar for incoming faculty. In D. R. Robertson \& L. B. Nilson (Eds.), To improve the academy: Vol. 25. Resources for faculty, instructional, and organizational development (pp. 327-344). Bolton, MA: Anker.

Sands, R. G., Parson, L. A., \& Duane, J. (1991). Faculty mentoring faculty in a public university. Journal of Higher Education, 62(2), 174-193.

Schrodt, P., Cawyer, C. S., \& Sanders, R. (2003). An examination of academic mentoring behaviors and new faculty members' satisfaction with socialization and tenure and promotion processes. Communication Education, $52(1), 17-29$.

Smith, J. O., Whitman, J. S., Grant, P. A., Stanutz, A., Russett, J. A., \& Rankin, K. (2001). Peer networking as a dynamic approach to supporting new faculty. Innovative Higher Education, 25(3), 197-207.

Smith, J. W., Smith, W. J., \& Markham, S. E. (2000). Diversity issues in mentoring academic faculty. Journal of Career Development, 26(4), 251-262.

Snelson, C. M., Martsolf, D. S., Dieckman, B. C., Anaya, E. R., Cartechine, K. A., Miller, B., et al. (2002). Caring as a theoretical perspective for a nursing faculty mentoring program. Nurse Education Today, 22(8), 654-660.

Solorzano, D. G. (1998). Role models, mentors, and the experiences of Chicana and Chicano Ph.D. scientists. Diversity in Higher Education, 2, 91-103.

Souba, W. W. (1999). Mentoring young academic surgeons, our most precious asset. Journal of Surgical Research, 82(2), 113-120.

Spencer, C., Tribe, K., \& Sokolovskaja, J. (2004). Mentoring made easy: A practical guide. Retrieved January 3, 2009, from www.eeo.nsw.gov.au/ publications_and_resources/publications/publication_list_-_new\#26618

St. Clair, K. L. (1994). Faculty-to-faculty mentoring in the community college: An instructional component of faculty development. Community College Review, 22(3), 23-36.

Steiner, J. F., Curtis, P., Lanphear, B. P., Vu, K. O., \& Main, D. S. (2004). Assessing the role of influential mentors in the research development of primary care fellows. Academic Medicine, 79(9), 865-872.

Tillman, L. C. (2001). Mentoring African American faculty in predominantly white institutions. Research in Higher Fducation, 42(3), 295-325.

Tracy, E. E., Jagsi, R., Starr, R., \& Tarbell, N. J. (2004). Outcomes of a pilot faculty mentoring program. American Journal of Obstetrics and Gynecology, 191(6), 1846-1850.

Waitzkin, H., Yager, J., Parker, T., \& Duran, B. (2006). Mentoring partnerships for minority faculty and graduate students in mental health services research. Academic Psychiatry, 30(3), 205-217. 
Woodd, M. (2001). Learning to leap from a peer: A research study on mentoring in a further and higher education institution. Research in PostCompulsory Education, 6(1), 97-104.

Wunsch, M. A. (1994a). Developing mentoring programs: Major themes and issues. In M. A. Wunsch (Ed.), New directions for teaching and learning: Vol. 57. Mentoring revisited: Making an impact on individuals and institutions (pp. 27-34). San Francisco: Jossey-Bass.

Wunsch, M. A. (1994b). Giving structure to experience: Mentoring strategies for women faculty. Initiatives, 56(1), 1-10.

Wunsch, M. A., \& Johnsrud, L. K. (1992). Breaking barriers: Mentoring junior faculty women for professional development and retention. In D. H. Wulff \& J. D. Nyquist (Eds.), To improve the academy: Vol. 11. Resources for faculty, instructional, and organizational development (pp. 175-187). Stillwater, OK: New Forums Press.

Yun, J. H., \& Sorcinelli, M. D. (2009). When mentoring is the medium: Lessons learned from a faculty development initiative. In L. B. Nilson \& J. E. Miller (Eds.), To improve the academy: Vol. 27. Resources for faculty, instructional, and organizational development (pp. 365-383). San Francisco: Jossey-Bass. 